\title{
Rain Water Use Efficiency of Rainfed Bt. Cotton (Gossypium hirsutum L.) as Influenced by Various Agronomic Practices
}

\author{
P. N. More*, M. P. Jagtap, D. N. Gokhale and A. J. Rathod \\ Department of Agronomy, VNMKV Parbhani, India \\ *Corresponding author
}

\section{A B S T R A C T}

\section{Keywords}

Rain water, $B t$. cotton (Gossypium hirsutum L.), Agronomic practices

\section{Article Info}

\section{Accepted:}

22 November 2020 Available Online: 10 December 2020
The field experiment was carried out at Research farm, Department of Agronomy, Vasantrao Naik Marathwada krishi Vidyapeeth, Parbhani during Kharif, 2018 with an object to find out the effect of various agronomic practices for rain water conservation on growth and yield of rainfed $B t$. cotton. The experiment was laid out in randomized block design, replicated thrice with seven treatments. Treatments adopted were $T_{1}$ - Opening furrow (Every row) $30 \mathrm{DAS}, \mathrm{T}_{2}$ - Opening furrow (Alternate row) $30 \mathrm{DAS}, \mathrm{T}_{3}-$ Straw mulching $30 \mathrm{DAS}, \mathrm{T}_{4}$ - Application of herbicide (Pyrithiobac sodium PE $\left.+\mathrm{POE}\right), \mathrm{T}_{5}-$ Application of Superabsorbent @ $5 \mathrm{~kg} \mathrm{ha}^{-1}, \mathrm{~T}_{6}$ - Intercropping (Cotton + soybean $\left.(1: 2)\right), \mathrm{T}_{7}$ - Control (No moisture conservation practices). seed cotton yield (kg ha $\left.{ }^{-1}\right)$ (2116.41), cotton stalk yield $\left(\mathrm{kg} \mathrm{ha}^{-1}\right)$ (3072.58), biological yield $\left(\mathrm{kg} \mathrm{ha}^{-1}\right)$ (5188.99), harvest index $(40.78 \%)$ and rain water use efficiency $(3.76 \mathrm{~mm})$ were recorded significantly in treatment $\mathrm{T}_{1}$ - Opening furrow (Every row) $30 \mathrm{DAS}$.

\section{Introduction}

Cotton is the most important fiber crop not only India but of the entire world. It provides the basic raw material to cotton textile industry. Cotton seed contains $15-20$ per cent oil and is used as vegetable oil and soap industries. After extraction of oil, the left over cake is rich in protein and used as cattle feed. Besides its vital role in national economy, its contribution in the foreign exchange is tremendous, nearly one third of India's export earnings are from textile sectors of which cotton alone constitutes nearly 70 per cent of raw material and provides employment to 60 million people. Cotton is cultivated both as irrigated and rainfed. In marathwada region cotton under rainfed conditions have to pass through at least one dry spell during its complete growth period, this leads to water stress which adversely effect on growth and development of plant (Sinclair, 2005). Rainfed agriculture has the problem of low productivity due to low moisture in Rhizosphere during dry spell. Appropriate moisture conservation measures are therefore necessary for improving soil moisture content and soil fertility (Surakod, Itnal 1997 and Patil, 1998).

Water use efficiency by crops can be improved by selection of crops and cropping 
systems based on available water supplies and increasing seasonal evapo-transpiration (ET) (parihar 2000). Seasonal evapo-transpiration is a measure of consumptive water use by the crops. Increasing the transpiration (T) component of evapo-transpiration (ET) results in higher utilization of water by the crops to increase the productivity. The rate of development of crop canopy and root system and the extent of soil wetting determine the relative fraction of ET lost as evaporation (E) or Transpiration (T). Seasonal evapotranspiration can be increased by selection of irrigation method, irrigation scheduling, tillage, mulching and fertilization (Saini and Chandra, 2010).

In many regions of India, expensive and energy consuming tillage operations, declining soil fertility and soil moisture limitation are major constraint for agricultural crop production, In rainy (kharif) season crops are dependent of rainwater while winter (rabi) season crops are dependent on conserved soil moisture (Dhar et al., 2008). The yield increase was correlated with increase in water contents in soil due to decrease in evaporation (Chuadhary et al., 2012).

The systems of managing crop residue on the soil surface or its incorporation need to be adopted for rainfed crops in India (kumar et al., 2006) with minimum or no tillage these are crucial in efficiently saving more precipitation for crop production. It is hypothesized that, cotton crop needs optimum soil moisture for better boll development hence, residual soil moisture which is conserved by following moisture conservation practices would enhance crop yield as well as water use efficiency. In this view the present study was planned to investigate the effect of different conservation agronomic practices on growth and yield of cotton under rainfed situations

\section{Materials and Methods}

A field experiment was conducted during Kharif season of 2018 at the research farm, Department of Agronomy, Vasantrao Naik Marathwada krishi Vidyapeeth, Parbhani (Maharashtra) geographically Parbhani is situated at $19^{\circ} 16^{\prime}$ North latitude and $76^{\circ} 47^{\prime}$ East longitude and at 409 altitude above sea level in Marathwada division encompassed by $17^{\circ} 35^{\prime}$ to $24^{\circ} 40^{\prime}$ North latitude and $74^{\circ} 49^{\prime}$ to $78^{\circ} 15^{\prime}$ East longitude geographical boundaries. Parbhani comes under subtropical climate with average annual precipitation of $885 \mathrm{~mm}$ distributed over 57 rainy days. The experimental field was leveled and soil was well drained, clayey in texture, medium in nitrogen, low in phosphorus and rich in potassium and slightly alkaline in reaction. During Kharif 2018-19, rainfall received 727 $\mathrm{mm}$ out of which effective rainfall was 562 $\mathrm{mm}$. The experiment was laid out in randomized block design, replicated thrice with seven treatments. moisture conservation treatment for enhancing rain water use efficiency adopted for Bt. cotton (Ajeet-155) were $T_{1}$ - Opening furrow (Every row) 30 DAS, $T_{2}$ - Opening furrow (Alternate row) 30 DAS, $T_{3}$ - Straw Mulching $30 \mathrm{DAS}, \mathrm{T}_{4}$ Application of herbicide (Pyrithiobac sodium $\mathrm{PE}+\mathrm{POE}), \mathrm{T}_{5}-$ Application of Superabsorbent @ $5 \mathrm{~kg} \mathrm{ha}^{-1}, \mathrm{~T}_{6} \quad$ Intercropping (Cotton + soybean (1:2)) and $\mathrm{T}_{7}$ - No moisture conservation practices (Control). Rainfed Bt. cotton was dibbled on spacing of $150 \times 30 \mathrm{~cm}$ on $3^{\text {rd }}$ July 2018 . Fertilizer dose of 120:60:60 Kg NPK/ha was administrated with nitrogen split of $50 \% \mathrm{~N}$ at the time of sowing and remaining $50 \% \mathrm{~N}$ at 30 DAS. Integrated plant protective measures were followed for control of pest and diseases are adopted. Five plants in each treatment in the net plot area were selected at random and tagged for biometric observations. The statistical analysis was done as per procedure suggested by Panse and Sukhatme (1967). 


\section{Effective rainfall}

Water in the root zone is measured by sampling and oven drying the soil before and after every shower of rain. The increase in soil moisture, plus evapo-transpiration loss (ETa) from the time the rain starts until the soil is sampled is the amount of effective rainfall. After heavy rainfall, evapotranspiration can be assumed to be at the potential rate during the short period from cessation of rainfall until the sampling time. This can be taken as 0.4 to 0.8 times the evaporation value of the class A Pan.

$\mathrm{ER}=\mathrm{M}_{2}-\mathrm{M}_{1}+\mathrm{Kp} \mathrm{Ep}$

Where,

$\mathrm{ER}=$ Effective rainfall

Ep $=$ Class a Pan Evaporation value

$M_{1} \& M_{2}=$ Moisture status in the effective root zone before and after rain respectively. $\mathrm{Kp}=$ Pan coefficient.

\section{Harvest index}

The harvest index is the ratio between seed cotton yield and the biological yield at harvest (Jain, 1972). It was calculated by the formula given below.

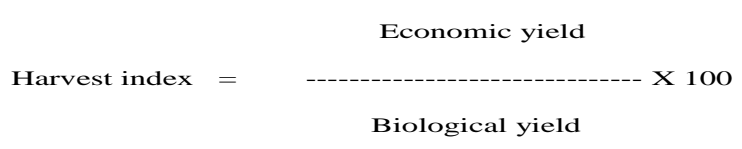

\section{Gross monetary return (GMR)}

The gross monetary returns $\left(₹ \mathrm{ha}^{-1}\right)$ from cotton crop were worked out by considering the seed cotton yield from different treatments and prevailing market price in both the seasons.

GMR $=$ Seed cotton yield $\mathrm{X}$ MSP

Where,
MSP $=$ Minimum support price $\left(\mathrm{q} \mathrm{ha}^{-1}\right)$

\section{Net monetary return (NMR)}

The Net monetary returns were worked out by subtracting the total cost of cultivation from the gross monetary return for the corresponding treatments.

NMR $=$ Gross monetary return - Cost of cultivation

\section{Benefit cost ratio}

The benefit cost ratio was worked out by using following formula.

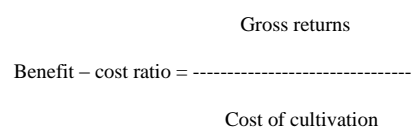

\section{Results and Discussion}

The effect of different agronomic practices on yield contributing characters and yield was observed to be significant.

\section{Yield attributing traits}

The highest number of picked bolls plant ${ }^{-1}$ were observed in treatment Opening furrow (Every row) 30 DAS $\left(T_{1}\right)$ which was followed by $\left(T_{2}\right)$ i.e. Opening furrow (Alternate row) 30 DAS, $\left(\mathrm{T}_{3}\right)$ Straw mulching $30 \mathrm{DAS},\left(\mathrm{T}_{4}\right)$ Application of herbicide (Pyrithioback sodium $\mathrm{PE}+\mathrm{POE})$ and $\left(\mathrm{T}_{5}\right)$ Application of Superabsorbent @ $5 \mathrm{Kg} \mathrm{ha}{ }^{-1}$. In $\left(\mathrm{T}_{6}\right)$ Intercropping (Cotton + soybean (1:2)) and $\left(\mathrm{T}_{7}\right)$ control (Recommended practices) recorded lowest number of picked bolls per plant were noticed. Similar result was reported by Saravanan et al., (2012), Nehra and yadav (2013) and Ganpati et al., (2018).

The data presented in table 1 revealed that the 
treatment $\left(\mathrm{T}_{1}\right)$ i.e. Opening furrow in (Every row) 30 DAS recorded the highest weight of bolls per plant (3.49) which was at par with treatment $\left(\mathrm{T}_{2}\right)$ Opening furrow in (Alternate row) and $\left(\mathrm{T}_{3}\right)$ Straw mulching $30 \mathrm{DAS}$ and found significantly superior over rest of the treatment. Similar observations were reported by Paslawar and Deotalu (2015).

\section{Yield}

Data regarding mean seed cotton yield $(\mathrm{kg}$ $\left.\mathrm{ha}^{-1}\right)$, cotton stalk yield $\left(\mathrm{kg} \mathrm{ha}^{-1}\right)$, biological yield $\left(\mathrm{kg} \mathrm{ha}^{-1}\right)$, harvest index $(\mathrm{HI})(\%)$ and rain water use efficiency $\left(\mathrm{Kg} \mathrm{ha}{ }^{-1} \mathrm{~mm}^{-1}\right)$ of rainfed Bt.cotton as influenced by different treatments are presented in Table 2.

\section{Seed cotton yield $\left(\mathrm{Kg} \mathrm{ha}^{-1}\right)$}

The data on mean seed cotton yield $\left(\mathrm{Kg} \mathrm{ha}^{-1}\right)$ as influenced by different treatments is presented in table 2 . The mean seed cotton yield was $1674.23 \mathrm{Kg} \mathrm{ha}^{-1}$. Treatment $\left(\mathrm{T}_{1}\right)$ Opening furrow (Every row) 30 DAS recorded highest seed cotton yield (2116.41 $\left.\mathrm{Kg} \mathrm{ha}^{-1}\right)$ which was at par with $\left(\mathrm{T}_{2}\right)$ Opening furrow in (Alternate row), $\left(\mathrm{T}_{3}\right)$ straw mulching, and significantly superior over rest. Control i.e. $\left(\mathrm{T}_{7}\right)$ recorded the lowest seed cotton yield (1311.84 $\left.\mathrm{Kg} \mathrm{ha}^{-1}\right)$.This result supported with findings by- Halemani et al., (2004), Rajendran et al., (2011) and Tayade and Meshram (2013).

\section{Cotton stalk yield (Kg ha $\left.{ }^{-1}\right)$}

The data on mean cotton stalk yield $\left(\mathrm{Kg} \mathrm{ha}^{-1}\right)$ as influenced by different treatments is presented in Table 2. The mean cotton stalk yield was $\left(2843.90 \mathrm{Kg} \mathrm{ha}^{-1}\right)$. Treatment $\left(\mathrm{T}_{1}\right)$ Opening Furrow (Every row) 30 DAS recorded highest cotton stalk yield (3072.58 $\left.\mathrm{Kg} \mathrm{ha}^{-1}\right)$ which was at par with $\left(\mathrm{T}_{2}\right)$ Opening furrow in (Alternate row) $30 \mathrm{DAS},\left(\mathrm{T}_{3}\right)$ straw mulching 30DAS, $\left(\mathrm{T}_{4}\right)$ application of herbicide (Pyrithioback sodium PE + POE) and $\left(\mathrm{T}_{5}\right)$ application of Superabsorbent @ 5 $\mathrm{Kg} \mathrm{ha}^{-1}$ and significantly superior over rest. Similar results were observed by Halemani et al., (2004), Rajendran et al., (2011) and Tayade and Meshram (2013).

\section{Biological yield $\left(\mathrm{Kg} \mathrm{ha}^{-\mathbf{1}}\right)$}

The data on mean biological yield $\left(\mathrm{Kg} \mathrm{ha}^{-1}\right)$ as influenced by different treatments were present in table 2 . The mean Biological yield was $\left(4514.18 \mathrm{Kg} \mathrm{ha}{ }^{-1}\right)$. Treatment $\left(\mathrm{T}_{1}\right)$ Opening Furrow (Every row) 30 DAS recorded highest biological yield $(5188.99 \mathrm{Kg}$ $\left.\mathrm{ha}^{-1}\right)$ whereas at par with $\left(\mathrm{T}_{2}\right)$ Opening furrow (Alternate row) $30 \mathrm{DAS},\left(\mathrm{T}_{3}\right)$ straw mulching 30 DAS, $\left(\mathrm{T}_{4}\right)$ Application of herbicide (Pyrithioback sodium PE + POE and $\left(\mathrm{T}_{5}\right)$ Application of Superabsorbent @ $5 \mathrm{Kg} \mathrm{ha}^{-1}$, and significantly superior over $\left(\mathrm{T}_{6}\right)$ i.e. Intercropping (Cotton + soybean (1:2)) and control $\left(\mathrm{T}_{7}\right)$. Lowest biological yield of 4212.65 Kg ha ${ }^{-1}$ was recorded by control $\left(\mathrm{T}_{7}\right)$. This result supported with findings by Paslawar and Deotalu (2015) and Ganpathi et al., (2018).

\section{Harvest Index (\%)}

The data on mean harvest index (\%) is presented in Table 2. Harvest index did not show much variation and ranged in between 31.14 to 40.58 . The mean harvest index (\%) was $(36.82 \%)$. Opening furrow (Every row) 30 DAS $\left(\mathrm{T}_{1}\right)$ treatment recorded highest harvest index $(40.78 \%)$.

\section{Rain water use efficiency $\left(\mathrm{Kg} \mathrm{ha}^{-1} \mathrm{~mm}^{-1}\right)$}

The data on Rain water use efficiency is presented in Table 2. Highest rain water use efficiency $\left(3.76 \mathrm{~kg} \mathrm{ha}^{-1} \mathrm{~mm}^{-1}\right)$ was recorded by opening furrow every row and least was recorded by control $\left(2.33 \mathrm{~kg} \mathrm{ha}^{-1} \mathrm{~mm}^{-1}\right)$. The increase in rain water use efficiency by 
various agronomic practices indicates more in conformity with - Ugale et al., (2000). conservation of rain water. These results are

Table.1 Number of picked bolls plant ${ }^{-1}$ and weight of bolls plant ${ }^{-1}$ as influenced by different agronomic practices in rainfed Bt. Cotton

\begin{tabular}{|c|c|c|c|}
\hline $\begin{array}{l}\text { Tr. } \\
\text { No. }\end{array}$ & Treatment & $\begin{array}{c}\text { Number of } \\
\text { picked bolls } \\
\text { plant }^{-1}\end{array}$ & $\begin{array}{l}\text { Weight } \\
\text { of bolls } \\
\text { plant }^{-1}\end{array}$ \\
\hline $\mathbf{T}_{1}$ & Opening furrow (Every row) 30 DAS & 29.18 & 3.49 \\
\hline $\mathbf{T}_{2}$ & Opening furrow (Alternate row) $30 \mathrm{DAS}$ & 26.30 & 3.37 \\
\hline $\mathbf{T}_{3}$ & Straw mulching 30 DAS & 27.70 & 3.41 \\
\hline $\mathbf{T}_{4}$ & Application of herbicide (Pyrithioback sodium PE + POE) & 22.76 & 3.32 \\
\hline $\mathbf{T}_{5}$ & Application of Superabsorbent @ $5 \mathrm{Kg} \mathrm{ha}^{-1}$ & 23.89 & 3.33 \\
\hline$T_{6}$ & Intercropping (Cotton + soybean $(1: 2))$ & 15.12 & 3.35 \\
\hline $\mathbf{T}_{7}$ & Control (Recommended practices) & 17.30 & 3.29 \\
\hline \multicolumn{2}{|c|}{$\mathbf{S E} \pm$} & 1.71 & 0.03 \\
\hline \multicolumn{2}{|c|}{ CD at $5 \%$} & 5.27 & 0.11 \\
\hline \multicolumn{2}{|c|}{ General mean } & 23.17 & 3.36 \\
\hline
\end{tabular}

Table. 2 Seed cotton yield $\left(\mathrm{kg} \mathrm{ha}^{-1}\right)$, cotton stalk yield $\left(\mathrm{kg} \mathrm{ha}^{-1}\right)$, biological yield $\left(\mathrm{kg} \mathrm{ha}^{-1}\right)$ and harvest index $(\%)$ and rain water use efficiency $\left(\mathrm{Kg} \mathrm{ha}^{-1} \mathrm{~mm}^{-1}\right)$ of rainfed $B t$. cotton as influenced by different treatments

\begin{tabular}{|c|c|c|c|c|c|c|}
\hline Tr.No. & Treatments & $\begin{array}{c}\text { Seed } \\
\text { cotton } \\
\text { yield } \\
\left(\mathbf{k g ~ h a}^{-1}\right)\end{array}$ & $\begin{array}{c}\text { Cotton } \\
\text { stalk } \\
\text { yield } \\
\left(\mathbf{k g ~ h a}^{-1}\right)\end{array}$ & $\begin{array}{c}\text { Biological } \\
\text { yield } \\
\left(\mathrm{kg} \mathrm{ha}^{-1}\right)\end{array}$ & $\begin{array}{c}\text { Harvest } \\
\text { index } \\
(\%)\end{array}$ & $\begin{array}{c}\text { RWUE } \\
\left(\mathrm{Kg} \mathrm{ha}^{-1}\right. \\
\left.{ }^{1} \mathrm{~mm}^{-1}\right)\end{array}$ \\
\hline $\mathbf{T}_{1}$ & $\begin{array}{l}\text { Opening Furrow (Every row) } 30 \\
\text { DAS }\end{array}$ & 2116.41 & 3072.58 & 5188.99 & 40.78 & 3.76 \\
\hline $\mathbf{T}_{2}$ & $\begin{array}{l}\text { Opening Furrow (Alternate row) } \\
30 \text { DAS }\end{array}$ & 1863.49 & 2958.93 & 4822.42 & 38.64 & 3.31 \\
\hline $\mathbf{T}_{3}$ & Straw mulching 30 DAS & 1945.82 & 3009.20 & 4955.02 & 39.26 & 3.45 \\
\hline $\mathbf{T}_{4}$ & $\begin{array}{l}\text { Application of herbicide } \\
\text { (Pyrithioback sodium PE }+ \text { POE) }\end{array}$ & 1635.41 & 2881.23 & 4514.65 & 36.22 & 2.90 \\
\hline $\mathbf{T}_{5}$ & $\begin{array}{l}\text { Application of Superabsorbent } \\
\text { @ } 5 \mathrm{Kg} \mathrm{ha}^{-1}\end{array}$ & 1719.87 & 2896.34 & 4684.88 & 36.71 & 3.05 \\
\hline $\mathbf{T}_{6}$ & $\begin{array}{l}\text { Intercropping [Cotton }+ \text { Soybean } \\
(1: 2)]\end{array}$ & $\begin{array}{c}1126.77 \\
(\mathrm{CEY}=573 . \\
22)\end{array}$ & $\begin{array}{c}2188.23 \\
(1657.41)\end{array}$ & $\begin{array}{c}3220.64 \\
(2525.94)\end{array}$ & 34.98 & 3.02 \\
\hline $\mathbf{T}_{7}$ & $\begin{array}{l}\text { Control (Recommended } \\
\text { practices). }\end{array}$ & 1311.84 & 2900.78 & 4212.65 & 31.14 & 2.33 \\
\hline & $\mathrm{SE} \pm$ & 111.09 & 146.64 & 317.45 & -- & 2.97 \\
\hline & CD at $5 \%$ & 346.10 & 456.86 & 989.00 & -- & \\
\hline & General mean & 1674.23 & 2843.90 & 4514.18 & 36.82 & \\
\hline
\end{tabular}


Table.3 Gross monetary returns (GMR) ( $\left.\boldsymbol{₹}^{-1} \mathrm{ha}^{-1}\right)$, cost of cultivation (COC) (₹ ha $\left.{ }^{-1}\right)$, net monetary returns (NMR) ( $\boldsymbol{F}^{-1} \mathrm{ha}^{-1}$ ) and benefit: cost ratio (B:C ratio) of rainfed Bt. cotton production system as influenced by different treatments

\begin{tabular}{|c|c|c|c|c|c|}
\hline $\begin{array}{l}\text { Tr. } \\
\text { No }\end{array}$ & Treatment & $\begin{array}{l}\text { GMR } \\
\left(\sum^{2} \mathbf{h a}^{-1}\right)\end{array}$ & $\begin{array}{l}\text { COC } \\
\left(\sum^{2} h^{-1}\right)\end{array}$ & $\begin{array}{l}\text { NMR } \\
\left(\sum^{-1} \mathbf{h a}^{-1}\right)\end{array}$ & B:C \\
\hline $\mathbf{T}_{1}$ & Opening furrow (Every row) $30 \mathrm{DAS}$ & 112067.70 & 53306.69 & 58761.01 & 2.10 \\
\hline $\mathbf{T}_{2}$ & $\begin{array}{l}\text { Opening furrow (Alternate row) } 30 \\
\text { DAS }\end{array}$ & 98928.66 & 50280.41 & 48648.66 & 1.96 \\
\hline $\mathbf{T}_{3}$ & Straw mulching 30 DAS & 103219.00 & 53771.38 & 49447.55 & 1.91 \\
\hline $\mathbf{T}_{4}$ & $\begin{array}{l}\text { Application of herbicide (Pyrithioback } \\
\text { sodium PE + POE) }\end{array}$ & 87105.16 & 43327.69 & 43777.47 & 2.01 \\
\hline $\mathbf{T}_{5}$ & $\begin{array}{l}\text { Application of Superabsorbent @ } 5 \\
\mathrm{Kg} \mathrm{ha}^{-1}\end{array}$ & 91469.66 & 51962.83 & 39506.83 & 1.76 \\
\hline$T_{6}$ & Intercropping (Cotton + soybean $(1: 2))$ & 89737.53 & 45999.93 & 43737.6 & 1.95 \\
\hline $\mathbf{T}_{7}$ & Control (Recommended practices) & 70460.54 & 44565.56 & 25894.98 & 1.58 \\
\hline & $\mathrm{SE} \pm$ & 5953.47 & -- & 3317.40 & -- \\
\hline & CD at $5 \%$ & 18343.29 & -- & 10221.28 & -- \\
\hline & General mean & 93418.57 & 49030.64 & 44253.22 & 1.89 \\
\hline
\end{tabular}

*MSP of cotton and soybean was 51.50 and $33.99 ₹ \mathrm{~kg}^{-1}$

\section{Economics}

Data on mean gross monetary returns (GMR) $\left(₹^{-} h^{-1}\right)$, cost of cultivation (COC) $\left(₹^{-} h^{-1}\right)$, net monetary returns (NMR) (₹ ha $\left.^{-1}\right)$ and benefit: cost ratio (B: $\mathrm{C}$ ratio) of rainfed $B t$. cotton production system as influenced by different treatments are presented in Table 3.

\section{Gross monetary return $\left(₹^{-1} h^{-1}\right)$}

Data on gross monetary return as influenced by various treatments presented in Table 3 . The mean gross monetary return was 93418.58 ₹ ha $^{-1}$. Treatment $\left(\mathrm{T}_{1}\right)$ Opening furrow (Every row) 30 DAS recorded highest gross monetary return $\left(112067.70 ₹\right.$ ha $\left.^{-1}\right)$ which was at par with $\left(\mathrm{T}_{2}\right)$ Opening furrow (Alternate row) and $\left(\mathrm{T}_{3}\right) 30$ DAS Straw mulching $30 \mathrm{DAS}$, and significantly superior over rest of the treatments. Control $\left(\mathrm{T}_{7}\right)$ treatment recorded the lowest gross monetary return (70460.54 ₹ $^{-1}$ ha. Similar kinds of observations were recorded by- Gaidhane et al., (2007), Narayana et al., (2011), Patode et al., (2017) and Basediya et al., (2018).

\section{Net monetary return $\left(\boldsymbol{F}^{\mathrm{h}} \mathrm{ha}^{-1}\right)$}

Data on net monetary return as influenced by various treatments presented in table 3 . The mean net monetary return recorded was (44253.22 $₹$ ha $\left.^{-1}\right)$. Treatment $\left(\mathrm{T}_{1}\right)$ Opening furrow (Every row) 30 DAS recorded highest net monetary return $\left(58761.01 \mathbf{F}^{-1} \mathrm{ha}^{-1}\right)$ which was at par with $\left(\mathrm{T}_{2}\right)$ Opening furrow (Alternate row) 30 DAS and $\left(\mathrm{T}_{3}\right)$ Straw mulching $30 \mathrm{DAS}$, and significantly superior over rest of the treatments.

Control $\left(\mathrm{T}_{7}\right)$ treatment recorded the lowest net monetary return $\left(25894.98 \mathbf{F}^{-1}\right.$ ha $\left.^{-1}\right)$. Similar kinds of result were recorded by- Narayana et al., (2011), Tayade and Meshram (2013) and Basediya et al., (2018). 


\section{Benefit: Cost ratio (B: C)}

Data on benefit cost ratio influenced by various treatments presented in Table 3 . The mean benefit cost ratio was (1.89). Treatment $\left(\mathrm{T}_{1}\right)$ and opening furrow every row recorded the highest benefit cost ratio is (2.1) application of herbicide (Pyrithioback sodium $\mathrm{PE}+\mathrm{POE}$ ) B:C Ratio recorded (2.01) due to its lower cost of cultivation. Control $\left(\mathrm{T}_{7}\right)$ treatment recorded the lowest benefit cost ratio of (1.58). Similar kinds of observations were recorded by- Narayana et al., (2011) and Basediya et al., (2018).

In conclusion the agronomic measures for moisture conservation in rainfed $B t$. cotton have significant influence on the growth, yield, productivity and economics among the various treatments. It can be concluded that, all moisture conservation measures have better effect on growth and yield as compared to control.

Highest seed cotton yield, biological yield, harvest index, rain water use efficiency, GMR, NMR and B:C ratio of rainfed Bt. cotton is achieved through Opening of furrow in (Every row) 30 DAS followed by Opening furrow (Alternate row) 30 DAS and Straw mulching 30 DAS due to rain water and moisture conservation.

\section{References}

Basediya, A.L., Mishara, S., Gupta, R., Kumar,P. and Basediya, S.S. 2018. Performance of Ridge and furrow System on the Growth and Yield Attribution of Soybean in Barwani District of M.P. India. Int.J.Curr. Microbiol. App.Sci. 7(8): 499-505.

Chuadhary, A. D., Yasin, M. and Rashid, M. 2012. Evaluation of rainfed rice to farm yard manure and soil compaction. International Rice Research. Newsletter,
IRRI, Philipines, 11: 32.

Dhar, S., Das, S. K., Kumar, S. and Singh, J. B. 2008. Effect of tillage and soil moisture conservation practices on crop yield of chickpea (Cicer arietinum) and soil properties under rainfed conditions. Indian Journal of Agricultural Sciences.78 (12): 1042-1053.

Gaidhane, S.N., Mankar P.B., Khawale, V.S. and Yepediwar M.D. 2007. Effect of land configuration and mulches on growth and yield of arborium cotton. $J$. Soils \& Crops. 17(2):403-406.

Ganpathi, S., Bharathi, S., Sree Rekha, M. and Jayalalitha, K. 2018. Effect of moisture conservation and nutrition management practices on leaf area, chlorophyll content and seed cotton yield of rainfed $B t$ cotton. Int. J. of che.stu. 6(5):539-542.

Halemani, H.L., Hallikeri, S.S., Antravali, M. B. and Nandagavi, R.A. 2002. Studies on dry sowing and rain water harvesting in rainfed cotton. Journal of Indian Society and Cotton Improvement. 27:9499.

Jain, H.K. 1972. Determination of harvest index India farm. 21: 527-530.

Kumar, R., Aryaand, R. L., and Mishra, J. P. 2006. Effect of seed priming and tillage management on productivity of chickpea genotype under rainfed conditions. Indian Journal of Agronomy. 51 (1): 5456.

Narayana, E., Aparna, D and Mridula, G.2011 Response of Bt. Cotton (Gossypium hirsutum L.) for integrated rain water and nutrient management. Journal of cotton research and Development. 25(1):68-70.

Nehra, P.L. and Yadav, P.S. 2013. Effect of moisture conservation and nutrient management for improvement in productivity and fibre quality of cotton. Journal of Cotton research and Development. 27(1):70-72. 
Panse, V.G. and Sukhatme, P.V. 1967. Statistical Methods for Agricultural Workers, $1^{\text {st }}$ Edn., ICAR, New Delhi.

Parihar, S.S., Gajri, P.R., Benbi, D.K. and Arora, V.K. 2000. Intensive cropping Efficient use of water, nutrients, and Tillage. Food Products Press. pp68.

Paslawar, A. N. and Deotalu, A. S. 2015. Impact of soil moisture conservation practices and nutrient management under high density planting syatem of cotton. Int. J. of Engi. And sci. Vol. 4 (9) pp-34-36.

Patode R.S., Nagdeve, M.B., Ganvir, M.M. and Gabhane, V.V. 2017 Evaluation of In-situ moisture conservation practices for sustainable production of major crops in Vidarbha Region. Int.J.Curr.Microbiol.App.Sci. $\quad$ 6(10): 261-268.

Rajendran, K., Mohamed, M.A. and Vaiyapuri, K. 2011. Influence on growth, yield attributes and yield of $B t$. cotton by soil and foliar application of nutrients. Madars Agricultural Journal. $98(1 / 3): 67-68$

Saini, S. and Chandra, S. 2010. - Water conservation and utilization in Agriculture production, Satish Serial Publishing House., Azadpur, New Delhi. Saravanan, M., Venkitaswamy, $\mathrm{R}$ and Rajendran, K. 2012. Influence of foliar nutrition on seed cotton yield and quality of Bt. cotton. Madars Agricultural Journal. 99 (4/6):332-334.

Sinclair, T. R. 2005. Theoretical analysis of soil and plant traits influencing daily plant water flux on drying soils. $J$. of Agronomy. 97: 1148-1152.

Surakod, V. S. and Itnal, C.J. 1998. Effect of tillage, moisture conservation and nitrogen on dry land rabi sorghum. $J$. of Maharashtra Agri. Univ. 22(3): 342344.

Tayade, A. S. and Meshram, M. K. 2013. Impact of dry sowing and in-situ moisture conservation on productivity of rainfed cotton. J. of cotton Res. Dev., 2013, 27, 1, 66-69.

Ugale, N. S., Shinde, S.H. and Jadhav, V.T. 2000. Response of chickpea var. Vijay to field layouts irrigation depths. $J$. Maharashtra Agri. Univ. 25(1):79-80.

\section{How to cite this article:}

More, P. N., M. P. Jagtap, D. N. Gokhale and Rathod, A. J. 2020. Rain Water Use Efficiency of Rainfed Bt. Cotton (Gossypium hirsutum L.) as Influenced by Various Agronomic Practices. Int.J.Curr.Microbiol.App.Sci. 9(12): 3045-3052. doi: https://doi.org/10.20546/ijcmas.2020.912.361 